\title{
PENGARUH RASIO LEVERAGE, LIKUIDITAS, PROFITABILITAS TERHADAP KUALITAS LABA PERUSAHAAN MAKANAN MINUMAN BEI
}

\author{
Nur Salma1, Tiara Januar Riska² \\ ${ }^{1,2}$ Universitas Mitra Indonesia, Fakultas Bisnis, Universitas Mitra Indonesia \\ ${ }^{1}$ salma@umitra.ac.id, ${ }^{2}$ tyarajariska@gmail.com
}

\begin{abstract}
ABSTRAK
Industri makanan dan minuman merupakan salah satu sektor penting dalam perekonomian Indonesia. Peluang untuk menanamkan investasi pada sektor makanan dan minuman ini sangat menjanjikan, karena pasar masih terbuka lebar dengan jumlah penduduk yang besar pula. Penelitian ini bertujuan untuk menguji pengaruh rasio leverage, rasio likuiditas dan rasio profitabilitas terhadap kualitas laba. Penelitian ini menggunakan analisis deskriptif dengan pendekatan kuantitatif. Variabel terikat adalah kualitas laba (Y), sedangkan variabel bebas yang digunakan yaitu rasio leverage $\left(\mathrm{X}_{1}\right)$, rasio likuiditas $\left(\mathrm{X}_{2}\right)$ dan rasio profitabilitas $\left(\mathrm{X}_{2}\right)$. Populasi dalam penilitian ini adalah seluruh perusahaan makanan dan minuman BEI periode tahun 2014-2018 yang berjumlah 18 perusahaan. Pengambilan sampel dalam penelitian ini menggunakan teknik purposive sampling sehingga diperoleh sebanyak 12 perusahaan yang dijadikan sampel. Pengujian dan analisis data dalam penilitian ini menggunakan uji asumsi klasik (uji normalitas, uji heteroskedastisitas, uji multikolinearitas dan uji autokolerasi), regresi linier berganda, koefisien determinasi $\left(\mathrm{r}^{2}\right)$ dan uji hipotesis (uji simultan (f) dan uji parsial (t)) dengan program SPSS 23. Hasil pengujian data menunjukkan bahwa secara simultan rasio leverage, rasio likuiditas dan rasio profitabilitas berpengaruh terhadap kualitas laba. Sedangkan pengujian secara parsial rasio leverage dan rasio profitabilitas berpengaruh terhadap kualitas laba, sedangkan likuiditas tidak berpengaruh terhadap kualitas laba perusahaan makanan dan minuman BEI.
\end{abstract}

Kata kunci: Kualitas Laba, Rasio Leverage, Rasio Likuiditas, Rasio Profitabilitas

\begin{abstract}
The food and baverage industry is one of the important sectors in the Indonesian economy. This study aims to examine the effect of leverage ratios, liquidity ratios an profitability ratios on earnings quality. The population in this study are all food and baverage sub-sector companies listed on the Indonesia Stock Exchange in the period 2014-2018 which amounted to 18 companies.

Sampling in this study used a purposive sampling techique so as many as 12 companies were obtained as sample. Testing and analysis of data in this study using multiple linier regression with SPSS 23 Program.

The result of data testing indicate that simultaneous leveage ratios, liquidity ratios and profitability ratios effect earnings qulity. While testing pasrtialy leverage ratios and profitability ratios affect the quality of earnings, whereas liquidity has no effect on earnings quality in food an baverage sub-sector companies that are listed on the Indonesia Stock Exchange.
\end{abstract}

Keyword: Earning Quality, Leverage Ratio, Liquidity Ratio, Profitability Ratio 


\section{PENDAhUluan}

Industri makanan dan minuman merupakan salah satu sektor penting dalam perekonomian Indonesia. Peluang untuk menanamkan investasi pada sektor makanan dan minuman ini sangat menjanjikan, karena pasar masih terbuka lebar dengan jumlah penduduk yang besar pula. Kementerian Perindustrian mencatat, sepanjang tahun 2018, industri makanan dan minuman mampu tumbuh sebesar 7,91 persen atau melampaui pertumbuhan ekonomi nasional di angka 5,17 persen. Selanjutnya, industri makanan menjadi salah satu sektor yang menopang peningkatkan nilai investasi nasional, yang pada tahun 2018 menyumbang hingga Rp56,60 triliun. Industri makanan menjadi kontributor terbesar hingga 26,67 persen. Perusahaan sub sektor makanan dan minuman merupakan perusahaan yang bergerak di bidang pembuatan produk kemudian dijual guna memperoleh keuntungan yang besar. Jumlah perusahaan makanan dan minuman yang terdaftar di Bursa Efek Indonesia cukup banyak. Ada 18 perusahaan sub sektor makanan dan minuman yang terdaftar di Bursa Efek Indonesia. Kualitas laba menjadi hal yang penting bagi para pemegang saham dan investor yang memanfaatkan informasi akuntansi sebagai dasar dalam pengambilan keputusan. Kualitas laba merupakan kualitas informasi laba yang tersedia untuk publik yang mampu menunjukkan sejauh mana laba dapat mempengaruhi pengambilan keputusan dan dapat digunakan investor untuk menilai perusahaan. Kualitas laba semakin tinggi jika mendekati perencanaan awal atau melebihi target dari rencana awal. Kualitas laba rendah jika dalam menyajikan laba tidak sesuai dengan laba sebenarnnya sehingga informasi yang di dapat dari laporan laba menjadi menyimpang dan dampaknya menyesatkan kreditor dan investor dalam mengambil keputusan. Terdapat beberapa faktor yang mempengaruhi kualitas laba itu sendirifaktor-faktor tersebut antara lain ukuran perusahaan, profitabilitas, likuiditas, kualitas akrual, leverage, dan masih banyak lainnya. Mengingat banyaknya faktor yang mempengaruhi kualitas laba, maka dalam penelitian ini hanya diuji beberapa faktor saja yaitu rasio leverage, rasio likuiditas dan rasio profitabilitas. Menurut Kasmir, 2017, 113; rasio leverage digunakan untuk mengukur sejauh mana aktiva perusahaan dibiayai dengan utang, artinya besarnya jumlah utang yang digunakan perusahaan untuk membiayai kegiatan usahanya jika dibandingkan dengan menggunakan modal sendiri. Rasio yang digunakan adalah debt ratio (rasio hutang). Menurut Irham Fahmi, 2014, 121; rasio likuiditas (liquidity ratio) adalah kemampuan suatu perusahaan memenuhi kewajiban jangka pendeknya secara tepat waktu, artinya apabila perusahaan ditagih, perusahaan akan mampu memenuhi utang tersebut terutama utang yang sudah jatuh tempo, oleh karena itu perhitungan rasio likuiditas tidak hanya berguna bagi perusahaan, namun juga bagi pihak luar perusahaan. Rasio likuiditas yang digunakan adalah current ratio (rasio lancar). Rasio likuiditas yang umum digunakan adalah current ratio. Menurut Kasmir, 2017, 196; rasio profitabilitas merupakan rasio untuk menilai kemampuan perusahaan untuk memperoleh laba atau keuntungan yang maksimal, disamping hal-hal lainnya, dengan memperoleh laba yang maksimal seperti yang telah ditargetkan, perusahaan dapat berbuat banyak bagi kesejahteraan pemilik, karyawan, serta meningkatkan mutu produk dan melakukan investasi baru. Rasio yang digunakan dalam penelitian ini adalah return on $\operatorname{asset}(R O A)$.

Tabel 1. Daftar kualitas laba perusahaan sub sektor makanan dan minuman tahun 2014-2018

\begin{tabular}{|c|l|r|r|r|r|r|}
\hline \multirow{2}{*}{ No } & \multirow{2}{*}{ Nama Perusahaan } & \multicolumn{5}{|c|}{ Kualitas Laba } \\
\cline { 3 - 7 } & & $\mathbf{2 0 1 4}$ & $\mathbf{2 0 1 5}$ & $\mathbf{2 0 1 6}$ & $\mathbf{2 0 1 7}$ & $\mathbf{2 0 1 8}$ \\
\hline 1 & PT. Tri Banyan Tirta Tbk & 1,05 & $-0,58$ & $-1,4$ & $-0,08$ & $-0,17$ \\
\hline 2 & PT. Cahaya Kalbar Tbk & $-1,42$ & 1,01 & 0,62 & 1,46 & 2,08 \\
\hline 3 & PT. Delta Djakarta Tbk & 0,46 & 0,99 & 0,79 & 0,93 & 0,78 \\
\hline 4 & PT. Indofood CBP Sukses Makmur Tbk & 1,12 & 0,09 & 1,12 & 0,99 & 0,92 \\
\hline 5 & PT. Indofood Sukses Makmur Tbk & 1,46 & 0,85 & 0,97 & 0,86 & 0,81 \\
\hline 6 & PT. Multi Bintang Indonesia Tbk & 0,08 & 1,36 & 0,95 & 0,75 & 0,84 \\
\hline 7 & PT. Mayora Indah Tbk & $-1,63$ & 1,42 & 0,36 & 0,58 & 0,19 \\
\hline 8 & PT. Prashida Aneka Niaga Tbk & $-1,16$ & 0,69 & $-2,41$ & $-0,46$ & $-0,82$ \\
\hline
\end{tabular}




\begin{tabular}{|c|l|r|r|r|r|r|}
\hline \multirow{2}{*}{ No } & \multicolumn{2}{|c|}{ Nama Perusahaan } & \multicolumn{5}{|c|}{ Kualitas Laba } \\
\cline { 3 - 7 } & & $\mathbf{2 0 1 4}$ & $\mathbf{2 0 1 5}$ & $\mathbf{2 0 1 6}$ & $\mathbf{2 0 1 7}$ & $\mathbf{2 0 1 8}$ \\
\hline 9 & PT. Nippon Indosari Corporindo Tbk & 1,44 & 0,15 & 1,12 & 1,99 & 1,58 \\
\hline 10 & PT. Sekar Bumi Tbk & 0,41 & 1,16 & $-1,1$ & $-2,16$ & $-1,71$ \\
\hline 11 & PT. Sekar Laut Tbk & 0,91 & 0,88 & 0,06 & 0,05 & 0,27 \\
\hline \multirow{2}{*}{12} & $\begin{array}{l}\text { PT. Ultrajaya Milk Industry and Trading } \\
\text { Company Tbk }\end{array}$ & 0,34 & 0,96 & 0,84 & 1,04 & 0,61 \\
\hline \multicolumn{2}{|c|}{ Rata-Rata } & $\mathbf{0 , 2 6}$ & $\mathbf{0 , 7 5}$ & $\mathbf{0 , 1 6}$ & $\mathbf{0 , 5 0}$ & $\mathbf{0 , 4 5}$ \\
\hline
\end{tabular}

Sumber : Data dari BEI dan www.idx.co.id (diolah tahun 2019)

Tabel 1. di atas menggambarkan data kualitas laba yang dihitung menggunakan arus kas operasi yang dibagi dengan EBIT pada perusahaan sub sektor makanan dan minuman yang terdaftar di Bursa Efek Indonesai. Pada tahun 2014 sebesar 0,26, pada tahun 2015 mengalami kenaikan sebesar 0,75, lalu pada tahun 2016 turun sangat drastis sebesar 0,16, pada tahun 2017 mengalami kenaikan lagi sebesar 0,50 dan pada tahun 2018 turun sebesar 0,45. Rata-rata kualitas laba pada perusahaan sub sektor makanan dan minuman mengalami fluktuasi pada setiap tahunnya.kualitas laba merupakan kualitas informasi laba yang tersedia untuk publik yang mampu menunjukkan sejauh mana laba dapat mempengaruhi pengambilan keputusan dan dapat digunakan investor untuk menilai perusahaan

Return On Asset (ROA) merupakan salah satu bentuk rasio profitabilitas yang digunakan untuk mengukur kemampuan perusahaan dalam menghasilkan keuntungan (profitabilitas) pada tingkat penjualan, aset, dan modal saham. Semakin tinggi nilai profitabilitas semakin tinggi kualitas laba, begitu juga sebaliknya.

Tabel 2. Daftar Debt Ratio perusahaan sub sektor makanan dan minuman tahun 2014-2018

\begin{tabular}{|c|l|r|r|r|r|r|}
\hline \multirow{2}{*}{ No } & \multicolumn{5}{|c|}{ Nama Perusahaan } & \multicolumn{5}{c|}{ Debt Ratio } \\
\cline { 3 - 7 } & & 2014 & 2015 & 2016 & 2017 & 2018 \\
\hline 1 & PT. Tri Banyan Tirta Tbk & 0,46 & 0,55 & 0,51 & 0,56 & 0,56 \\
\hline 2 & PT. Cahaya Kalbar Tbk & 0,58 & 0,57 & 0,38 & 0,35 & 0,16 \\
\hline 3 & PT. Delta Djakarta Tbk & 0,24 & 0,18 & 0,15 & 0,15 & 0,16 \\
\hline 4 & PT. Indofood CBP Sukses Makmur Tbk & 0,42 & 0,38 & 0,36 & 0,36 & 0,34 \\
\hline 5 & PT. Indofood Sukses Makmur Tbk & 0,53 & 0,53 & 0,47 & 0,47 & 0,48 \\
\hline 6 & PT. Multi Bintang Indonesia Tbk & 0,75 & 0,64 & 0,64 & 0,58 & 0,61 \\
\hline 7 & PT. Mayora Indah Tbk & 0,63 & 0,54 & 0,52 & 0,51 & 0,51 \\
\hline 8 & PT. Prashida Aneka Niaga Tbk & 0,41 & 0,48 & 0,57 & 0,57 & 0,65 \\
\hline 9 & PT. Nippon Indosari Corporindo Tbk & 0,55 & 0,56 & 0,47 & 0,38 & 0,34 \\
\hline 10 & PT. Sekar Bumi Tbk & 0,53 & 0,44 & 0,33 & 0,37 & 0,41 \\
\hline 11 & PT. Sekar Laut Tbk & 0,59 & 0,51 & 0,48 & 0,52 & 0,55 \\
\hline \multirow{2}{*}{12} & $\begin{array}{l}\text { PT. Ultrajaya Milk Industry and Trading } \\
\text { Company Tbk }\end{array}$ & 0,22 & 0,21 & 0,18 & 0,19 & 0,14 \\
\hline \multicolumn{2}{|c|}{ Rata-Rata } & $\mathbf{0 , 4 9}$ & $\mathbf{0 , 4 7}$ & $\mathbf{0 , 4 2}$ & $\mathbf{0 , 4 2}$ & $\mathbf{0 , 4 1}$ \\
\hline
\end{tabular}

Sumber : Data dari BEI dan www.idx.co.id (diolah tahun 2019)

Tabel 2 di atas menggambarkan data debt ratio yang dihitung menggunakan total liabilitas yang dibagi dengan total aset pada perusahaan sub sektor makanan dan minuman yang terdaftar di Bursa Efek Indonesai. Pada tahun 2014 sebesar 0,49, pada tahun 2015 mengalami penurunan sebesar 0,47, pada tahun 2016 turun sebesar 0,42, pada tahun 2017 sebesar 0,42dan pada tahun 2018 turun sebesar 0,41. Rata-rata debt ratio perusahaan mengalami penurunan pada setiap tahunnya. Berdasarkan hasil pengukuran, Apabila rasionya tinggi, artinya pendanaan dengan utang semakin banyak, maka semakin sulit bagi perusahaan untuk memperoleh tambahan pinjaman karena dikhwatirkan perusahaan tidak mampu menutupi utang- utangnya dengan aktiva yang dimilikinya. 
Tabel 3. Daftar Current Ratio perusahaan sub sektor makanan dan minuman tahun 2014-2018

\begin{tabular}{|c|l|r|r|r|r|r|}
\hline \multirow{2}{*}{ No Nama Perusahaan } & \multicolumn{5}{c|}{ Current Ratio } \\
\cline { 3 - 6 } & & 2014 & 2015 & 2016 & 2017 & 2018 \\
\hline 1 & PT. Tri Banyan Tirta Tbk & 1,91 & 2,98 & 1,96 & 2,19 & 2,61 \\
\hline 2 & PT. Cahaya Kalbar Tbk & 2,02 & 2,01 & 2,19 & 2,22 & 5,11 \\
\hline 3 & PT. Delta Djakarta Tbk & 4,41 & 6,42 & 7,61 & 8,64 & 7,21 \\
\hline 4 & PT. Indofood CBP Sukses Makmur Tbk & 2,19 & 2,33 & 2,41 & 2,43 & 2,09 \\
\hline 5 & PT. Indofood Sukses Makmur Tbk & 1,81 & 2,71 & 1,51 & 1,51 & 2,72 \\
\hline 6 & PT. Multi Bintang Indonesia Tbk & 2,38 & 2,08 & 2,43 & 1,79 & 2,83 \\
\hline 7 & PT. Mayora Indah Tbk & 2,09 & 2,37 & 2,25 & 2,39 & 2,65 \\
\hline 8 & PT. Prashida Aneka Niaga Tbk & & & & & \\
& & 1,46 & 1,21 & 3,06 & 2,16 & 4,02 \\
\hline 9 & PT. Nippon Indosari Corporindo Tbk & 3,37 & 2,05 & 2,96 & 2,26 & 3,57 \\
\hline 10 & PT. Sekar Bumi Tbk & 1,48 & 1,28 & 2,11 & 3,64 & 3,38 \\
\hline 11 & PT. Sekar Laut Tbk & 2,41 & 3,26 & 2,83 & 2,36 & 2,27 \\
\hline \multirow{2}{*}{12} & PT. Ultrajaya Milk Industry and Trading & & & & & \\
& Company Tbk & 3,34 & 3,75 & 4,84 & 4,19 & 4,41 \\
\hline & Rata-Rata & $\mathbf{2 , 4 1}$ & $\mathbf{2 , 7 0}$ & $\mathbf{3 , 0 1}$ & $\mathbf{2 , 9 8}$ & $\mathbf{3 , 5 7}$ \\
\hline
\end{tabular}

Sumber : Data dari BEI dan www.idx.co.id(diolah tahun 2019)

Tabel 3 di atas menggambarkan data current ratio yang dihitung menggunakan aktiva lancar yang dibagi dengan uhutang lancar pada perusahaan sub sektor makanan dan minuman yang terdaftar di Bursa Efek Indonesai. Pada tahun 2014 sebesar 2,41, mengalami peningkatan pada tahun 2015 sebesar 2,70, pada tahun 2016 sebesar 3,01, pada tahun 2017 turun sebesar 2,98dan pada tahun 2018 sebesar 3,57. Rata-rata current ratio perusahaan mengalami fluktuasi pada setiap tahunnya.Current ratio yang tinggi biasanya dianggap menunjukkan tidak terjadi masalah dalam likuiditas, sehingga semakin tinggi likuiditas artinya laba yang dihasilkan suatu perusahaan berkualitas karena manajemen perusahaan tidak perlu melakukan praktik manajemen laba.

Tabel 4 Daftar Return On Asset perusahaan sub sektor makanan dan minuman tahun 2014-2018

\begin{tabular}{|c|l|r|r|r|r|r|}
\hline \multirow{2}{*}{ No Nama Perusahaan } & \multicolumn{5}{c|}{ Return On Asset } \\
\cline { 3 - 7 } & & 2014 & 2015 & 2016 & 2017 & 2018 \\
\hline 1 & PT. Tri Banyan Tirta Tbk & $-0,01$ & $-0,02$ & $-0,02$ & $-0,06$ & $-0,03$ \\
\hline 2 & PT. Cahaya Kalbar Tbk & 0,03 & 0,07 & 0,18 & 0,08 & 0,08 \\
\hline 3 & PT. Delta Djakarta Tbk & 0,29 & 0,18 & 0,21 & 0,21 & 0,22 \\
\hline 4 & PT. Indofood CBP Sukses Makmur Tbk & 0,11 & 0,11 & 0,13 & 0,11 & 0,14 \\
\hline 5 & PT. Indofood Sukses Makmur Tbk & 0,06 & 0,04 & 0,06 & 0,06 & 0,05 \\
\hline 6 & PT. Multi Bintang Indonesia Tbk & 0,36 & 0,24 & 0,43 & 0,53 & 0,42 \\
\hline 7 & PT. Mayora Indah Tbk & 0,04 & 0,11 & 0,11 & 0,11 & 0,11 \\
\hline 8 & PT. Prashida Aneka Niaga Tbk & $-0,06$ & $-0,07$ & $-0,06$ & 0,05 & $-0,07$ \\
\hline 9 & PT. Nippon Indosari Corporindo Tbk & 0,09 & 0,11 & 0,11 & 0,03 & 0,04 \\
\hline 10 & PT. Sekar Bumi Tbk & 0,14 & 0,05 & 0,02 & 0,02 & 0,01 \\
\hline 11 & PT. Sekar Laut Tbk & 0,05 & 0,05 & 0,04 & 0,04 & 0,04 \\
\hline 12 & PT. Ultrajaya Milk Industry and Trading Company Tbk & & & & & \\
& & 0,11 & 0,15 & 0,17 & 0,14 & 0,13 \\
\hline \multicolumn{1}{|c|}{ Rata-Rata } & $\mathbf{0 , 1 0}$ & $\mathbf{0 , 0 9}$ & $\mathbf{0 , 1 2}$ & $\mathbf{0 , 1 1}$ & $\mathbf{0 , 1 0}$ \\
\hline
\end{tabular}

Sumber : Data dari BEI dan www.idx.co.id(diolah tahun 2019)

Tabel 1.5 di atas menggambarkan data return on asset yang dihitung menggunakan laba besih yang dibagi dengan total aktiva pada perusahaan sub sektor makanan dan minuman yang terdaftar di Bursa Efek Indonesai. Pada tahun 2014 sebesar 0,10, pada tahun 2015 sebesar 0,09, pada tahun 2016 sebesar 
0,12, pada tahun 2017 sebesar 0,11dan pada tahun 2018 sebesar 0,10. Rata-rata return on asset perusahaan mengalami fluktuasi pada setiap tahunnya.

Penulis tertarik untuk melakukan sebuah penelitian pada perusahaan sub sektor makanan dan minuman yang terdaftar di Bursa Efek Indonesai dengan memberi judul "Pengaruh Rasio Leverage, Rasio Likuiditas dan Rasio Profitabilitas Terhadap Kualitas Laba Pada Perusahaan Sub Sektor Makanan dan Minuman Yang Terdaftar Di Bursa Efek Indonesia”.

\section{LANDASAN TEORI}

\section{Rasio Keuangan}

Menurut Irham Fahmi, 2014, 107; secara sederhana rasio disebut sebagai perbandingan jumlah, dari satu jumlah lainnya itulah dilihat perbandingannya dengan harapan nantinya akan ditemukan jawaban yang selanjutnya itu dijadikan bahan kajian untuk dianalisis dan diputuskan. Kualitas Laba

Kualitas laba adalah laba di dalam laporan keuangan yang mencerminkan kinerja keuangan perusahaan yang sesungguhnya. Menurut Ervin, 2016, 8; mencerminkan kinerja keuangan perusahaan yang sesungguhnya

$$
\text { Kualitas Laba }=\frac{\text { Arus Kas Operasi }}{\text { EBIT }}
$$

\section{Rasio Leverage}

Menurut Kasmir, 2017, 113; rasio leverage merupakan rasio yang digunakan untuk mengukur sejauh mana aktiva perusahaan dibiayai dengan utang. Artinya besarnya jumlah utang yang digunakan perusahaan untuk membiayai kegiatan usahanya jika dibandingkan dengan menggunakan modal sendiri. Dalam penelitian ini rasio leverage diukur menggunakan debt to total asset ratio / debt ratio.

\section{Rasio Likuiditas}

$$
\text { Debt to Total Asset Ratio }=\frac{\text { Total Liabilitas }}{\text { Total Aset }}
$$

Menurut Fred Weston dalam bukunya Kasmir, 2017, 129; menyebutkan bahwa rasio likuiditas (liquidity ratio) merupakan rasio yang menggambarkan kemampuan perusahaan dalam memenuhi kewajiban (utang) jangka pendek, artinya apabila perusahaan ditagih, perusahaan akan mampu untuk memenuhi utang tersebut terutama utang yang sudah jatuh tempo. Rasio likuiditas yang umum digunakan adalah current ratio. Menurut Kasmir, 2017, 134; current ratio merupakan rasio untuk mengukur kemampuan perusahaan dalam membayar kewajiban jangka pendek atau utang yang segera jatuh tempo pada saat ditagih secara keseluruhan.

$$
C R=\frac{\text { Aktiva lancar }}{\text { Utang lancar }}
$$

\section{Rasio Profitabilitas}

Menurut Kasmir, 2017, 196; rasio profitabilitas merupakan rasio untuk menilai kemampuan perusahaan dalam mencari keuntungan. Rasio ini juga memberikan ukuran tingkat efektivitas manajemen suatu perusahaan Penggunaan rasio profitabilitas dapat dilakukan dapat digunakan dengan menggunakan perbandingan antara berbagai komponen yang ada di laporan keuangan. Pengukuran dapat dilakukan untuk beberapa periode operasi. Tujuannya adalah agar terlihat perkembangan perusahaan dalam rentang waktu tertentu, baik penurunan atau kenaikan.

Dalam penelitian ini profitabilitas perusahaan dihitung dengan Return On Asset (ROA). rasio yang menunjukkan hasil (return) atas jumlah aktiva yang digunakan dalam perusahaan. 


$$
R O A=\frac{\text { Laba Bersih }}{\text { Total Aktiva }} \times 100 \%
$$

\section{METODE PENELITIAN}

\section{Desain Penelitian}

Dalam penelitian ini menggunakan analisis deskriptif dengan pendekatan kuantitatif. Variabel terikat adalah kualitas laba $(\mathrm{Y})$, sedangkan variabel bebas yang digunakan yaitu rasio leverage $\left(\mathrm{X}_{1}\right)$, rasio likuiditas $\left(\mathrm{X}_{2}\right)$ dan rasio profitabilitas $\left(\mathrm{X}_{2}\right)$. Kerangka pikir digambarkan sebagai berikut.

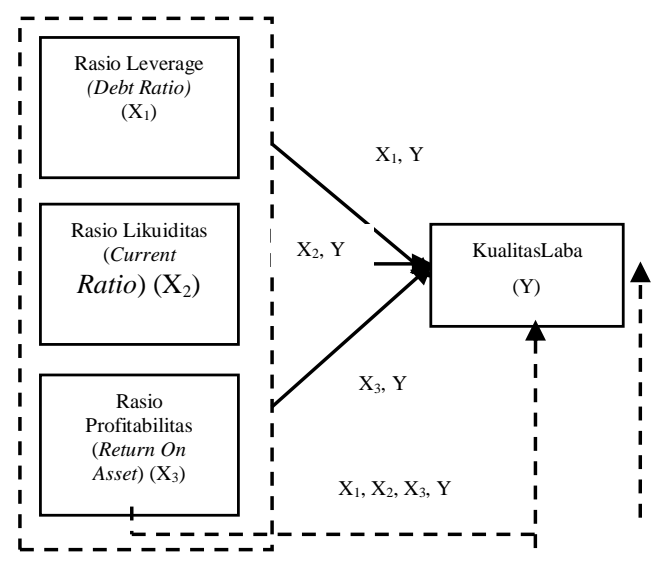

\section{Gambar 3.1 Kerangka Pikir}

Sumber: Data diolah peneliti tahun 2019

\section{Populasi dan Sampel}

1) Populasi

Menurut Sugiyono, 2016, 80;Populasi adalah wilayah generalisasi yang terdiri atas: objek atau subyek yang mempunyai kualitas dan karakteristik tertentu yang ditetapkan oleh peneliti untuk dipelajari dan kemudian ditarik kesimpulannya. Populasi dalam penelitian sebanyak 18 perusahaan.

2) Sampel

Sampel dalam penelitian sebanyak 18 perusahaan sub sektor makanan dan minuman, sedangkan sampel sejumlah 12 perusahaan periode tahun 2014-2018.

\section{Alat Analisis}

1. Uji Asumsi Klasik

a. Uji Normalitas

Menurut Misbahuddin dan Iqbal Hasan, 2014, 278; uji normalitas adalah uji persyaratan tentang kelayakan data untuk di analisis dengan menggunakan statistik parametik atau statistik nonparametik. Uji normalitas bertujuan untuk menguji apakah data pada variabel terikat, variabel bebas, atau keduanya mempunyai distribusi normal atau tidak. Model regresi yang baik adalah memiliki distribusi data normal atau mendekati normal, sedangkan distribusi normal dapat diketahui dengan melihat penyebaran data statistik pada sumbu diagonal dari grafik distribusi normal. Analisis grafik yang digunakan untuk menguji normalitas data dalam penelitian ini menggunakan probability plot.

b. Uji Heteroskedastisitas

Menurut Imam Ghozali, 2013, 105; uji heterokedastisitas bertujuan menguji apakah dalam model regresi terjadi ketidaksamaan varian dari residual satu pengamatan ke pengamatan yang lain. Model regresi yang baik adalah yang tidak terjadi heterokedastisitas. 
Metode dapat dipakai untuk mendeteksi gejala atau masalah heteroskedastisitas dalam penelitian ini adalah metode grafik. Uji heteroskedastisitas dilakukan dengan melihat grafik plot antara nilai prediksi variabel terikat (ZPRED) dengan residualnya (SRESID). Menggunakan gambar scatterplot untuk menganalisis apakah terjadi heterokedastisitas atau terjadi homokedastisitas dengan mengamati penyebaran titk-titik pada gambar.

c. Uji Multikolinearitas

Menurut Imam Ghozali, 2013, 154; uji ini dimaksudkan untuk mendeteksi gejala korelasi antara variabel independen yang satu dengan variabel independen yang lain. Pada model regresi yang baik seharusnya tidak terdapat korelasi di antara variabel independen. Uji Multikolinieritas dapat dilakukan dengan 2 cara yaitu dengan melihat VIF (Variance Inflation Factors) dan nilai tolerance. Jika VIF $>10$ dan nilai tolerance $<0,10$ maka terjadi gejala Multikolinieritas.

d. Uji Autokolerasi

Menurut Imam Ghozali, 2013, 105;uji autokorelasi bertujuan untuk menguji apakah dalam model regresi linear ada korelasi antara kesalahan pengganggu pada periode $t$ dengan periode $t-1$ sebelumnya. Jika terjadi korelasi, maka dinamakan problem autokorelasi. Autokorelasi muncul karena observasi yang berurutan sepanjang waktu berkaitan satu sama lain.Masalah ini timbul karena residual (kesalahan pengganggu) tidak bebas dari satu observasi ke observasi lainnya.

Untuk mendeteksi gejala autokorelasi dapat dilakukan dengan pengujian Durbin-Watson (DW). Hasil perhitungan Durbin-Watson (d) dibandingkan dengan nilai dtabel pada $\alpha=0,05$. Tabel d memiliki dua nilai yaitu batas atas (du) dan nilai batas bawah(dl)untuk berbagi nilai $\mathrm{n}$ (jumlah sampel) dan k (jumlah variabel independen).

2. Koefisien Determinasi $\left(\mathrm{R}^{2}\right)$

Menurut Ghozali,2013, 96; koefisien determinasi $\left(\mathrm{R}^{2}\right)$ pada intinya mengukur seberapa jauh kemampuan model dalam menerangkan variasi variabel dependen. Nilai keofisien determinasi antara nol dan satu. Nilai $\left(\mathrm{R}^{2}\right)$ yang kecil berarrti kemampuan variabel independennya dalam menjelaskan variasi variabel dependen amat terbatas.

3. Analisis Regresi Berganda

Metode analisis yang digunakan adalah regresi linier berganda. Menurut Sugiyono, 2016, 88; regresi linear berganda adalah regresi linear dimana variabel terikatnya (variabel Y) dihubungkan dengan dua atau lebih variabel bebas (variabel X). Dalam penelitian ini analisis regresi dilakukan untuk mengetahui pola hubungan antara variabel independen leverage (debt ratio) $\left(\mathrm{X}_{1}\right)$, likuiditas (current ratio) $\left(\mathrm{X}_{2}\right)$, dan profitabilitas (return on asset)) $\left(\mathrm{X}_{3}\right)$ dengan variabel dependen (kualitas laba) $(\mathrm{Y})$. Analisis data yang digunakan dalam penelitian ini dengan model sebagai berikut :

$$
\mathbf{Y}=\mathbf{a}+\mathbf{b}_{1} \mathbf{X}_{1}+\mathbf{b}_{2} \mathbf{X}_{2}+\mathbf{b}_{3} \mathbf{X}_{3}+\mathbf{e}
$$

Keterangan :

$\mathrm{Y} \quad=$ Kualitas Laba

$\mathrm{a} \quad=$ Konstanta

$\mathrm{X}_{1} \quad=$ Rasio Leverage (Debt Ratio)

$\mathrm{X}_{2} \quad=$ Rasio Likuiditas (Current Ratio)

$\mathrm{X}_{3} \quad=$ Rasio Profitabilitas (Return On Asset)

$\mathrm{B}=$ Koefisien Regresi dari masing masing variabel indipenden.

e $\quad=$ Error term

4. Uji Hipotesis

a. Uji F

Menurut Misbahuddin dan Iqbal Hasan, 2014, 159; uji F (uji serentak/simultan) yaitu statistik bagi koefisien regresi serentak atau bersama-sama memengaruhi Y. Menurut Imam Ghozali, 2016, 96; uji statistik F menguji joint hipotesis bahwa $b_{1}, b_{2}$, dan $b_{3}$ secara simultan. Uji statistik F pada dasarnya menunjukan apakah semua variabel independen atau bebas yang dimasukan dalam model mempunyai pengaruh secara bersama-sama terhadap variabel dependen atau terikat.

b. Uji t

Menurut Misbahuddin dan Iqbal Hasan, 2014, 160; uji t (regresi parsial) yaitu statistik bagi koefisien regresi dengan hanya satu koefisien regresi memenuhi Y. Menurut Imam Ghozali, 
2013, 98; uji statistik t pada dasarnya menunjukkan seberapa jauh pengaruh satu variabel independen secara individual dalam menerangkan variabel dependen.

\section{Tempat dan Waktu Penelitian}

Penelitian ini dilakukan di Bursa Efek Indonesia Kantor Perwakilan Lampung yang terletak di Jalan Jenderal Sudirman No. 5D Bandar Lampung, telepon (0721 260-188). Waktu penelitian yaitu dari bulan April sampai dengan selesai.

\section{Teknik Pengumpulan Data}

1. Dokumentasi

Metode ini merupakan suatu cara untuk mendapatkan atau mencari data mengenai hal-hal variabel berupa catatan, laporan keuangan, transkip, buku-buku, surat kabar, majalah,dan sebagainya. Pengumpulan data dalam penelitian ini dilakukan dengan metodedokumentasi terhadap laporan keuangan perusahaan sub sektor makanan dan minuman yangterdaftar di Bursa Efek Indonesia dan memenuhi kriteria pengambilan sampel. Cara yang dilakukan yaitu dengan mengumpulkan laporan tahunan perusahaan yang diperoleh melalui kantor Bursa Efek Indonesia Perwakilan Lampung dan www.idx.co.id.

2. Studi Pustaka

Studi pustaka adalah teknik pengumpulan data yang diperoleh dari membaca, mempelajari, dan menganalisis literatur yang bersumber dari buku buku dan jurnal ilmiah yang berkiatian dengan penelitian.

\section{Definisi Operasional Variabel}

Menurut Sumadi dalam Chairul Anwar, 2017, 24; definisi operasional adalah definisi yang didasarkan atas sifat-sifat hal yang didefinisikan yang dapat diamati. Definisi operasional menjelaskan cara tertentu yang digunakan untuk meneliti dan mengoperasikan konstrak, sehingga memungkinkan bagi peneliti yang lain untuk melakukan replikasi pengukuran dengan cara yang sama atau mengembangkan cara pengukuran konstrak yang lebih baik.

Tabel 3.4 Definisi Operasional Variabel

\begin{tabular}{|c|c|c|c|c|}
\hline $\begin{array}{c}\text { Varia } \\
\text { bel }\end{array}$ & Konsep & Indikator & Parameter & $\begin{array}{l}\text { Skala } \\
\text { Ukur }\end{array}$ \\
\hline $\begin{array}{l}\text { Kualit } \\
\text { as } \\
\text { Laba }\end{array}$ & $\begin{array}{l}\text { Menurut Ervin, 2016, 8; } \\
\text { mencerminkan kinerja } \\
\text { keuangan perusahaan yang } \\
\text { sesungguhnya }\end{array}$ & $\begin{array}{l}\text { 1) Arus Kas } \\
\text { Operasi } \\
\text { 2) EBIT }\end{array}$ & Kualitas Laba $=\frac{\text { Arus Kas Operasi }}{E B I T}$ & Rasio \\
\hline $\begin{array}{l}\text { Laver } \\
\text { age }\end{array}$ & $\begin{array}{l}\text { Menurut Kasmir, 2017, } \\
151 \text {; digunakan untuk } \\
\text { mengukur sejauh mana } \\
\text { aktiva perusahaan dibiayai } \\
\text { dengan utang. }\end{array}$ & $\begin{array}{l}\text { 1) Total Liabilitas } \\
\text { 2) Total Asset }\end{array}$ & Debt Ratio $=\frac{\text { Total Liabilitas }}{\text { Total Aset }}$ & Rasio \\
\hline $\begin{array}{l}\text { Likui } \\
\text { ditas }\end{array}$ & $\begin{array}{l}\text { Menurut Kasmir, 2017, } \\
129 \text {; untuk mengukur } \\
\text { kemampuan perusahaan } \\
\text { dalam } \\
\text { kewajibannya yang sudah } \\
\text { jatuh tempo. }\end{array}$ & $\begin{array}{l}\text { 1) Aktiva Lancar } \\
\text { 2) Hutang Lancar }\end{array}$ & $C R=\frac{\text { Aktiva lancar }}{\text { Hutang lancar }}$ & Rasio \\
\hline $\begin{array}{l}\text { Profit } \\
\text { abilita } \\
\text { s }\end{array}$ & $\begin{array}{l}\text { Menurut Kasmir, } 2017, \\
196 ; \text { untuk menilai } \\
\text { kemampuan perusahaan } \\
\text { dalam } \\
\text { keuntungan. }\end{array}$ & $\begin{array}{l}\text { 1) Laba Bersih } \\
\text { 2) Total Aktiva }\end{array}$ & $R O A=\frac{\text { Laba Bersih }}{\text { Total Aktiva }} \times 100 \%$ & Rasio \\
\hline
\end{tabular}


Sumber : Jurnal Penelitian Terdahulu (Data diolah lagi oleh penulis)

\section{Pengolahan Data}

1) Editing adalah pengecekan atau pengkoreksian data yang telah dikumpulkan karena kemungkinan data yang masuk atau data yang di kumpulkan tidak logis atau meragukan

2) Tabulasi adalah membuat tabel-tabel yang berisikan data yang telah diberi kode sesuai dengan yang dibutuhkan.

\section{Hasil dan Pembahasan}

\section{Uji Asumsi Klasik}

Uji Normalitas

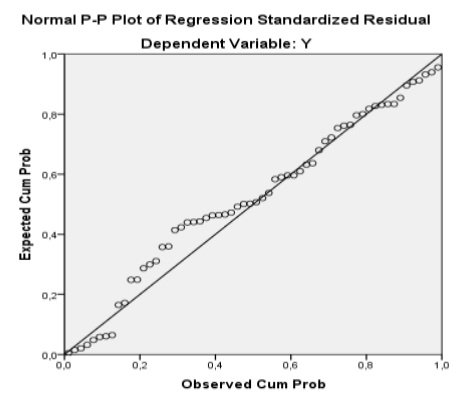

Berdasarkan gambar diatas dapat disimpulkan bahwa data dalam penelitian ini memenuhi syarat normal probability plot sehingga model regresi dalam penelitian memenuhi asumsi normalitas yang artinya data dalam penelitian ini berasal dari populasi yang berdistribusi normal.

Uji Heteroskedastisitas

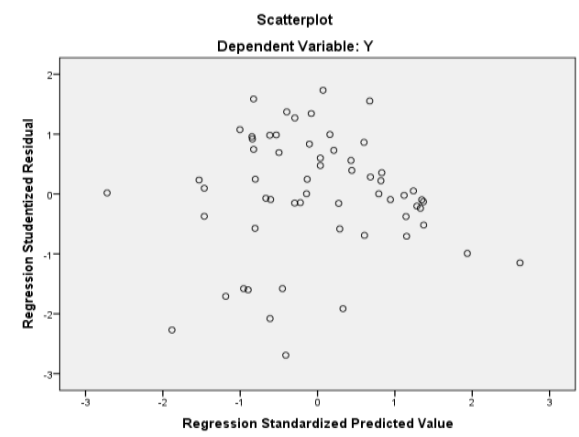

Berdasarkan gambar diatas dapat dilihat tidak ada pola tertentu serta titik-titik menyebar di atas dan bawah angka nol pada sumbu Y, sehingga dapat diartikan tidak terjadi heteroskedastisitas.

Uji Multikolinearitas Coefficients $^{\mathrm{a}}$

\begin{tabular}{|ll|r|r|}
\hline \multirow{2}{*}{ Model } & \multicolumn{2}{|c|}{ Collinearity Statistics } \\
\cline { 2 - 3 } & Tolerance & \multicolumn{2}{|c|}{ VIF } \\
\hline 1 & Constant) & & \\
& $\mathrm{X}_{1}$ &, 543 & 1,843 \\
$\mathrm{X}_{2}$ &, 515 & 1,942 \\
$\mathrm{X}_{3}$ &, 931 & 1,075 \\
\hline
\end{tabular}

a. Dependent Variable: $\mathrm{Y}$

Diketahui bahwa nilai tolerance untuk semua variabel lebih besar dari 0,1 dan nilai VIF untuk semua variabel lebih kecil dari 10. Dengan demikian dapat disimpulkan bahwa tidak terjadi gejala multikolinearitas pada semua variabel. 
Uji Autokolerasi

Nilai durbin watson adalah 1,766, nilai batas atas du sebesar 1.6889 lebih kecil dari durbin Watson dan kurang dari 4 - batas atas (4 - 1.6889), maka dapat disimpulkan bahwa tidak terjadi autokorelasi dalam model regresi ini.

\section{Analisis Regresi Berganda}

\begin{tabular}{|c|c|c|c|c|c|c|}
\hline \multirow[b]{3}{*}{ Model } & \multicolumn{4}{|c|}{ ficients $^{\mathrm{a}}$} & \multirow[b]{3}{*}{$\mathrm{t}$} & \multirow[b]{3}{*}{ Sig. } \\
\hline & \multicolumn{2}{|c|}{ Unstandardized Coefficients } & \multicolumn{2}{|l|}{ Standardized Coefficients } & & \\
\hline & B & Std. Error & Beta & & & \\
\hline 1 (Constant) & 1,684 & ,714 & & & 2,360 & ,022 \\
\hline $\mathrm{X}_{1}$ & $-2,561$ & 1,045 & &,- 394 & $-2,451$ & 017 \\
\hline $\mathrm{X}_{2}$ &,- 157 & , 109 & &,- 237 & $-1,438$ & 156 \\
\hline $\mathrm{X}_{3}$ & 3,230 & 1,015 & & ,390 & 3,182 &, 002 \\
\hline
\end{tabular}

a. Dependent Variable: $\mathrm{Y}$

Berdasarkan tabel diatas dapat diperoleh persamaan sebagai berikut :

Kualitas Laba $=1,684-2,561 X_{1}-0,157 X_{2}+3,230 X_{3}+e$

Keterangan :

$\mathrm{Y} \quad=$ Kualitas Laba

$\mathrm{X}_{1} \quad=$ Rasio Leverage (Debt Ratio)

$\mathrm{X}_{2} \quad=$ Rasio Likuiditas (Current Ratio)

$\mathrm{X}_{3} \quad=$ Rasio Profitabilitas (Return On Asset)

$\mathrm{e} \quad=$ Error

Bentuk persamaan regresi diatas dapat diartikan bahwa :

1) a (konstanta $)=1,684$ berarti jika variabelkualitas laba pada perusahaan sub sektor makanan dan minuman dianggap konstan, maka kualitas laba sebesar 1,684.

2) Nilai $\mathrm{b}_{1}=-2,561$ koefisien regresi laverage (Debt Ratio) $\left(\mathrm{X}_{1}\right)$ sebesar -2,561 menunjukan bahwa laverage (Debt Ratio) $\left(\mathrm{X}_{1}\right)$ yang artinya jika leverage (debt ratio) $\left(\mathrm{X}_{1}\right)$ mengalami peningkatan satu satuan maka tingkat kualitas laba (Y) akan mengalami penurunan sebesar 2,561, dengan asumsi variabel independen lainnya konstan. Hal ini menunjukan adanya pengaruh negatif antara rasio laverage (Debt Ratio )dengan kualitas laba..

3) Nilai $\mathrm{b}_{2}=-0,157$ koefisien regresi likuiditas (Current ratio) $\left(\mathrm{X}_{2}\right)$ sebesar $-0,157$ menunjukan bahwa likuiditas (Current ratio) $\left(\mathrm{X}_{2}\right)$ yang artinya jika Current ratio $\left(\mathrm{X}_{2}\right)$ mengalami peningkatan satu satuan maka tingkat kualitas laba (Y) akan mengalami penurunan sebesar 0,157 , dengan asumsi variabel independen lainnya konstan. Hal ini menunjukan adanya pengaruh negatif antara rasio likuiditas (Current ratio) dengan kualitas laba..

4) Nilai $b_{3}=3,230$ koefisien regresi profitabilitas (Return On Asset) $\left(\mathrm{X}_{3}\right)$ sebesar 3,230 menunjukan bahwa profitabilitas (Return On Asset) $\left(\mathrm{X}_{3}\right)$ yang artinya jika ROA $\left(\mathrm{X}_{3}\right)$ mengalami peningkatan satu satuan maka tingkat kualitas laba (Y) akan mengalami peningkatan sebesar 3,230, dengan asumsi variabel independen lainnya konstan. Hal ini menunjukan adanya pengaruh positif antara rasio profitabilitas (ROA) dengan kualitas laba.

\section{Koefisien Determinasi $\left(\mathbf{R}^{2}\right)$}

\begin{tabular}{|l|r|r|r|rr|}
\hline $\begin{array}{l}\text { Mod } \\
\text { el }\end{array}$ & $\mathrm{R}$ & $\mathrm{R}$ Square & Adjusted R Square & \multicolumn{2}{|c|}{ Std. Error of the Estimate } \\
\hline 1 &, $465^{\mathrm{a}}$ &, 216 &, 174 & & \\
\hline
\end{tabular}

a. Predictors: (Constant), $\mathrm{X}_{3}, \mathrm{X}_{2}, \mathrm{X}_{1}$

b. Dependent Variable: Y 
Berdasarkan tabel diatas dapat diketahui nilai R square sebesar 0,216 atau 21,60 \% maka kualitas laba (Y) dapat dijelaskan oleh $\mathrm{X}_{1}, \mathrm{X}_{2}$, dan $\mathrm{X}_{3}$ sebesar 21,60\% dan sisanya sebesar 78,40\% dijelaskan oleh faktor lain diluar penelitian.

\section{Uji Hipotesis}

\section{Uji Simultan $(\mathrm{F})$}

Hasil uji $\mathrm{F}$ menunjukan nilai $\mathrm{F}$ hitung 5,152> F tabel 2,77 dan nilai signifikan F 0,003<0,05. ini berarti variabel laverage (Debt Ratio) $\left(\mathrm{X}_{1}\right)$, likuiditas (Current Ratio) $\left(\mathrm{X}_{2}\right)$ dan profitabilitas (ROA) $\left(\mathrm{X}_{3}\right)$ bersama-sama (simultan) berpengaruh dan signifikan terhadap kualitas laba (Y).

Uji Parsial (t)

\begin{tabular}{|c|c|c|c|c|c|c|}
\hline \multirow{2}{*}{\multicolumn{2}{|c|}{ Model }} & \multicolumn{2}{|c|}{ Unstandardized Coefficients } & \multirow{2}{*}{$\begin{array}{c}\text { Standardized Coefficients } \\
\text { Beta } \\
\end{array}$} & \multirow[b]{2}{*}{ 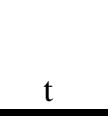 } & \multirow[b]{2}{*}{ Sig. } \\
\hline & & B & Std. Error & & & \\
\hline \multirow[t]{4}{*}{1} & (Constant) & 1,684 & ,714 & & 2,360 & ,022 \\
\hline & $\mathrm{X}_{1}$ & $-2,561$ & 1,045 &,- 394 & $-2,451$ & ,017 \\
\hline & $\mathrm{X}_{2}$ &,- 157 & , 109 &,- 237 & $-1,438$ & , 156 \\
\hline & $X_{3}$ & 3,230 & 1,015 & ,390 & 3,182 &, 002 \\
\hline
\end{tabular}

a. Dependent Variable: Y

Berdasarkan tabel 4.7 diatas maka dapat diketahui bahwa :

a) Hasil uji $\mathrm{t}$ untuk variabel debt ratio diperoleh nilai $\mathrm{t}_{\text {hitung }}$ sebesar 2,451, jika dibandingkan dengan nilai $\mathrm{t}$ tabel sebesar 2,00324, maka $\mathrm{t}_{\text {hitung }}>\mathrm{t}$ tabel nilai sig $0,017<0,05$. Maka $\mathrm{H}_{1}$ yang menyatakan rasiolaverage (debt ratio) berpengaruh terhadap kualitas laba diterima. Dengan demikian dapat disimpulkan bahwa debt ratio berpengaruh terhadap kualitas laba pada perusahaan sub sektor makanan dan minuman yang terdaftar di Bursa Efek Indonesia.

b) Hasil uji $\mathrm{t}$ untuk variabel CR diperoleh nilai $\mathrm{t}$ hitung sebesar 1,438, jika dibandingkan dengan nilai $\mathrm{t}$ tabel sebesar 2,00324, maka $\mathrm{t}$ hitung $<\mathrm{t}$ tabel nilai sig $0,156>0,05$. Maka $\mathrm{H}_{2}$ yang menyatakan rasiolikuiditas (current ratio) berpengaruh terhadap kualitas laba ditolak. Dengan demikian dapat disimpulkan bahwa current ratio tidak berpengaruh terhadap kualitas laba pada perusahaan sub sektor makanan dan minuman yang terdaftar di Bursa Efek Indonesia.

c) Hasil uji $t$ untuk variabel ROA diperoleh nilai $t_{\text {hitung }}$ sebesar 3,182, jika dibandingkan dengan nilai $t$ tabel sebesar 2,00324, maka $\mathrm{t}$ hitung $>\mathrm{t}$ tabel nilai sig $0,002<0,05$. Maka $\mathrm{H}_{3}$ yang menyatakan rasio profitabilitas (return on asset) berpengaruh terhadap kualitas laba diterima. Dengan demikian dapat disimpulkan bahwa rasio profitabilitas (ROA) berpengaruh terhadap kualitas laba pada perusahaan sub sektor makanan dan minuman yang terdaftar di Bursa Efek Indonesia.

\section{KESIMPULAN DAN SARAN}

\section{Kesimpulan}

Berdasarkan hasil penelitian dapat diambil kesimpulan sebagai berikut :

1) Rasio laverage (debt ratio) secara parsial berpengaruh terhadap kualitas laba pada perusahaan sub sektor makanan dan minuman yang terdaftar di Bursa Efek Indonesia tahun 2014-2018.

2) Rasio likuiditas (current ratio) secara parsial tidak berpengaruh terhadap kualitas laba pada perusahaan sub sektor makanan dan minuman yang terdaftar di Bursa Efek Indonesia tahun 20142018.

3) Rasio profitabilitas (return on asset) secara parsial berpengaruh terhadap kualitas laba pada perusahaan sub sektor makanan dan minuman yang terdaftar di Bursa Efek Indonesia tahun 20142018.

4) Rasio laverage (debt ratio), rasio likuiditas (current ratio), dan rasio profitabilitas (return on asset) secara simultan (bersama-sama) berpengaruh terhadap kualitas laba pada perusahaan sub sektor makanan dan minuman yang terdaftar di Bursa Efek Indonesia tahun 2014-2018. Perubahan kualitas 
laba dapat dijelaskan variebel bebas sebesar 21,60\% dan sisanya sebesar 78,40 \% dijelaskan oleh faktor lain diluar penelitian yang tidak di teliti oleh peneliti.

\section{Saran}

Untuk Penelitian Selanjutnya

1) Penelitian selanjutnya disarankan melakukan penelitian dengan populasi dalam penelitian tidak hanya terbatas pada satu jenis perusahaan yaitu perusahaan sub sektor makanan dan minuman.

2) Sebaiknya menambah jumlah variabel bebas, agar hasil penelitian dapat lebih baik lagi.

3) Penelitian selanjutnya disarankan agar periode penelitian yang digunakan selalu menggunakan tahun penelitian yang terbaru.

\section{REFERENSI}

Irham Fahmi. 2014. Analisis Laporan Keuangan. Bandung: CV Alfabeta

Ervin Yuliskarlina. 2016. Analisis Faktor-Faktor Yang Mempengaruhi Kualitas Laba Perusahan Pada Industri Barang Konsumsi Yang Terdaftar Di Bursa Efek Indonesia. STIE Perbanas Surabaya

Kasmir. 2017. Analisis Laporan Keuangan. Jakarta: Rajawali Pers

Sugiyono. 2016. Metode Penelitian Kuantitatif, Kualitatif, dan R\&D. Bandung : CV Alfabeta

Misbahuddin dan Iqbal Hasan. 2014. Analisis Data Penelitian Dengan Statistika. Jakarta: Bumi Aksara

Ghozali.Imam. 2013. Aplikasi Analisis Multivariate dengan Program SPSS. Semarang : Badan Penerbit Universitas Diponegoro

Anwar, Chairul. 2017. Metodologi Penelitian. Bandar Lampung : Badan Penerbit Universitas Bandar Lampung

Bagus Rahmat Setiawan. 2017. Pengaruh Ukuran Perusahaan, Profitabilitas, Likuiditas, dan Leverage Terhadap Kualitas Laba Pada Perusahaan Industri Barang Konsumsi yang Terdaftar di BEI. Sekolah Tinggi Ilmu Ekonomi (STIE) Galileo Batam

http://kemenperin.go.id/artikel/20298/Industri-Makanan-dan-Minuman-Jadi-Sektor-Kampiun-(diakses 15Maret)

https://idx.co.id/perusahaan-tercatat/laporan-keuangan-dan-tahunan/(diakses 20 Maret 2019)

https://www.sahamok.com/emiten/sektor-industri-barang-konsumsi/sub-sektor-makanan-minuman/ (diakses 12 Maret 2019) 